\title{
HUBUNGAN JUMLAH TROMBOSIT DAN NILAI AGREGASI TROMBOSIT PADA PASIEN DIABETES MELITUS TIPE 2 RSUP PROF. DR. R. D. KANDOU MANADO
}

\author{
Maya F. Memah \\ Bagian Patologi Klinik Fakultas Kedokteran Universitas Sam Ratulangi Manado \\ Email:maya_memah@yahoo.com
}

\begin{abstract}
Patients with type 2 diabetes mellitus (T2DM) are characterized by an acceleration of thrombopoiesis, an increase of platelet turnover, and a decrease of platelet survival time. These conditions affect the platelet count that manifest as an increase of the proportion of large and reactive platelets which are more thrombogenic. This study aimed to obtain the correlation between the platelet count and the platelet aggregation value in T2DM patients. This was an observational analytical study using the Pearson correlation test. Subjects were 30 T2DM outpatients at Endocrine-Metablolic Clinic of Prof. Dr. R.D. Kandou Hospital Manado. Blood samples of all patients were examined for platelet count and platelet aggregation value. The results showed that most of the subjects were $\geq 50$ tahun (86.7\%). Mean thrombocyte count was within normal level. Platelet aggregation values of the ADP $10 \mu \mathrm{m}$ showed hypoaggregation, meanwhile of the ADP $5 \mu \mathrm{m}$ showed normoaggregation The Pearson correlation test showed that there was no significant correlation between the platelet count and the platelet aggregation value, either using $10 \mu \mathrm{m}$ ADP $(P=0.22)$ or using $5 \mu \mathrm{m}$ ADP $(P=$ 0.08). Conclusion: There was no significant correlation between the platelet count and the platelet aggregation values in patients with type-2 diabetes mellitus at Endocrine-Metabolic Clinic of Prof. Dr. R.D. Kandou Hospital Manado.
\end{abstract}

Keywords: platelet count, platelet aggregation, T2DM

\begin{abstract}
Abstrak: Pada pasien diabetes melitus tipe 2 (DMT2) terjadi percepatan trombopoiesis, peningkatan pergantian trombosit, dan penurunan waktu hidup trombosit. Hal-hal tersebut dapat memengaruhi jumlah trombosit, yang menyebabkan terjadinya peningkatan trombosit berukuran lebih besar dan reaktif yang lebih bersifat trombogenik. Penelitian ini bertujuan untuk mendapatkan hubungan antara jumlah trombosit dan nilai agregasi trombosit pada pasien DMT2. Penelitian ini bersifat observasional analitik dengan menggunakan uji korelasi Pearson. Subjek penelitian berjumlah 30 pasien DMT2 di Poliklinik Edokrin-Metabolik RSUP Prof. Dr. R. D. Kandou Manado. Sampel darah dilakukan pemeriksaan jumlah trombosit dan nilai agregasi trombosit. Hasil penelitian memperlihatkan bahwa subjek penelitian terbanyak pada usia tuæ 50 tahun (86,7\%). Rerata jumlah trombosit masih dalam rentang normal, sedangkan nilai agregasi trombosit dengan ADP $10 \mu \mathrm{m}$ menunjukkan hipoagregasi dan yang dengan ADP $5 \mu \mathrm{m}$ menunjukkan normoagregasi. Hasil uji korelasi Pearson menunjukkan tidak terdapat hubungan bermakna antara jumlah trombosit dan nilai agregasi trombosit baik dengan ADP $10 \mu \mathrm{m}(P=0,22)$ maupun ADP $5 \mu \mathrm{m}(P=0,08)$. Simpulan: Pada pasien DMT2 di Poliklinik Edokrin-Metabolik RSUP Prof. Dr. R. D. Kandou Manado tidak terdapat hubungan bermakna antara jumlah trombosit dan nilai agregasi trombosit.
\end{abstract}

Kata kunci: jumlah trombosit, sgregasi trombosit, DMT2 
Pada diabetes melitus tipe 2 (DMT2) sel-sel beta pankreas kurang mampu menyintesis dan melepaskan insulin. Jumlah yang disekresi tidak mencukupi jumlah yang dibutuhkan atau penurunan sensitivitas jaringan terhadap insulin ${ }^{1}$ yang berakibat terganggunya metabolisme karbohidrat, lemak, dan protein. Hasil Riset Kesehatan Dasar (Riskesdas) tahun 2007 memperlihatkan bahwa proporsi penyebab kematian akibat DMT2 pada kelompok usia 45-54 tahun di daerah perkotaan menduduki ranking ke-2 yaitu 14,7\%. Dari 10 negara yang diperkirakan mempunyai jumlah penyandang DMT2 terbanyak di dunia, Indonesia menempati peringkat ke- 4 . $^{2}$

Aktivitas trombosit pada pasien meningkat yang berdampak peningkatan agregasi trombosit dan risiko aterotrombosis. Pada terjadi disfungsi trombosit serta aktivasi abnormal trombosit yang menyebabkan mikro atau makro-angiopati dan hiperaktivitas trombosit. ${ }^{3}$ Terdapat 3 perubahan utama dari fungsi trombosit pada DMT2 yaitu trombosit imatur, lebih besar dan lebih reaktif yang disintesis dari sumsum tulang; trombosit teraktivasi ketika terpajan oleh metabolic mileu pada DMT2; dan trombosit teraktivasi karena cedera pembuluh darah. ${ }^{4}$ Disfungi trombosit berperan terhadap perkembangan gangguan trombotik dan komplikasi vaskular pada . ${ }^{5}$

Jumlah trombosit pada tergantung pada beberapa variabel, yaitu waktu hidup trombosit, tingkat produksi trombosit, dan tingkat pergantian trombosit pada DMT2. Pada DMT2 terjadi penurunan waktu hidup trombosit dan peningkatan pergantian trombosit (platelet turnover). Pergantian trombosit yang meningkat berakibat trombosit menjadi lebih besar dan reaktif pada proses hemostasis yang memroduksi banyak tromboksan A2; ${ }^{7}$ selain itu, trombosit yang lebih besar bersifat lebih trombogenik. $^{8}$

Peningkatan agregasi trombosit yang direspon dengan adenosine difosfat (ADP), trombin, kolagen, asam arakidonat, dan epinefrin lebih terlihat pada pasien DMT2 dibandingkan yang non-DMT2. Pada kondisi in vitro, trombosit yang distimulasi dengan agonis trombosit menunjukkan penurunan ambang batas tahanan untuk agregasi trombosit. $^{3}$

Agregasi adalah kemampuan trombosit melekat satu sama lain untuk membentuk suatu sumbatan. Agregasi awal terjadi akibat kontak permukaan dan pembebasan ADP dari trombosit lain yang melekat ke permukaan endotel; hal ini disebut gelombang agregasi primer. Seiring dengan makin banyaknya trombosit yang terlibat, maka lebih banyak ADP yang dibebaskan sehingga terjadi gelombang agregasi sekunder disertai rekrutmen trombosi yang lebih banyak. Agregasi berkaitan dengan perubahan bentuk trombosit dari diskoid menjadi sferikal dengan pseupoda., ${ }^{5,9}$ Saat trombosit bersinggungan dengan pembuluh darah yang cedera, terutama dengan serabut kolagen di dinding pembuluh, sifat-sifat trombosit segera berubah secara drastis. Trombosit mulai membengkak, bentuknya menjadi iregular dengan tonjolan - tonjolan yang mencuat dari permukaannya. ${ }^{10}$ Perubahan bentuk awal dan agregasi primer masih reversibel, sedangkan gelombang agregasi sekunder merupakan suatu fenomena ireversibel. ${ }^{9,10}$

Pengikatan ADP yang dibebaskan dari trombosit aktif ke membran trombosit akan mengaktifkan enzim fosfolipase, yang menghidrolisis fosfolipid di membran trombosit untuk menghasilkan asam arakidonat. Asam arakidonat adalah prekursor mediator kimiawi yang sangat kuat baik pada agregasi maupun inhibisi agregasi yang terlibat dalam jalur prostaglandin. Melalui proses ini, asam arakidonat diubah dalam sitoplasma trombosit oleh enzim siklooksigenase menjadi endoperoksida siklik, PGG2, dan PGH2. Stimulator kuat untuk 
agregasi trombosit, yaitu senyawa tromboksan $\mathrm{A}_{2}$, dihasilkan oleh kerja enzim tromboksan sintetase pada berbagai endoperoksida siklik. Tromboksan $\mathrm{A}_{2}$ merupakan senyawa yang sangat aktif tetapi tidak stabil, yang mengalami penguraian menjadi tromboksan $\mathrm{B}_{2}$ yang stabil dan inaktif. Tromboksan $\mathrm{A}_{2}$ juga merupakan vasokonstriktor kuat yang akan mencegah pengeluaran darah lebih lanjut dari pembuluh yang rusak. ${ }^{5}$

\section{METODE PENELITIAN}

Penelitian ini bersifat observasional analitik dengan menggunakan uji korelasi Pearson. Subjek penelitian terdiri dari 30 pasien DMT2 di Poliklinik EndokrinMetabolik Bagian Penyakit Dalam RSUP Prof. Dr. R. D. Kandou Manado. Sampel darah yang diambil diperiksa untuk jumlah trombosit dan nilai agregasi trombosit.

\section{HASIL DAN BAHASAN}

Jumlah keseluruhan sampel darah pada penelitian ini yaitu 30. Tabel 1 memperlihatkkan bahwa sebagian besar sampel telah berusiæ50 tahun ( 86,7\%). Jenis kelamin laki-laki dan perempuan memiliki distribusi yang sama yaitu masing-masing sebanyak 15 orang (50\%).

Tabel 1. Frekuensi data karakteristik subjek

\begin{tabular}{ccc}
\hline \multicolumn{1}{c}{ Karakteristik } & $\begin{array}{c}\text { Frekuensi } \\
\mathrm{N}=30\end{array}$ & $\%$ \\
\hline Usia & & \\
\hline $\begin{array}{c}\text { Dewasa } \\
\leq 49 \mathrm{Thn}\end{array}$ & 4 & 13,3 \\
\hline $\begin{array}{c}\text { Tua } \\
\geq 50 \mathrm{Thn}\end{array}$ & 26 & 86,7 \\
\hline Jenis kelamin & & \\
\hline Laki - laki & 15 & 50 \\
\hline Perempuan & 15 & 50 \\
\hline
\end{tabular}

Menurut WHO, ${ }^{5}$ peningkatan prevalensi usia penyandang DMT2 di negara berkembang yaitu $\geq 45$ tahun keatas, dan bertambahnya usia merupakan salah satu faktor risiko terjadinya penyakit DMT2. Hasil penelitian ini menunjukkan jumlah usia tuæ ( 50 tahun) lebih banyak dibandingkan usia dewasa ( $\leq 49$ tahun).

Pada Tabel 2, rerata jumlah trombosit 289.330/ $\mathrm{mm}^{3}$ masih dalam rentang jumlah

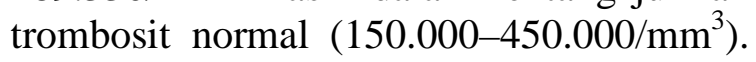
Hasil nilai agregasi dari Laboratorium Prokita Manado yaitu nilai ADP $10 \mu \mathrm{m}$ 4984\% dan nilai ADP $5 \mu \mathrm{m}$ 25-68\%. Nilai rerata agregasi trombosit dengan ADP 10 $\mu \mathrm{m} \quad 41,83 \%$ dengan interpretasi hipoagregasi, dan nilai rerata agregasi trombosit dengan ADP $5 \mu \mathrm{m}$ 44,23\% dengan interpretasi normoagregasi. Hal ini bisa dikarenakan pengaruh obat antidiabetik. ${ }^{12}$

Tabel 2. Data deskriptif dan uji normalitas jumlah trombosit, nilai agregasi ADP $10 \mu \mathrm{m}$ dan nilai agregasi ADP $5 \mu \mathrm{m}$

\begin{tabular}{lccccc}
\hline & Mean & $\begin{array}{c}\text { Std. } \\
\text { Dev. }\end{array}$ & $\begin{array}{c}\text { Mini } \\
\text { mum }\end{array}$ & $\begin{array}{c}\text { Maxi } \\
\text { mum }\end{array}$ & $\begin{array}{c}\text { Kolmo- } \\
\text { gorov- } \\
\text { Smirnov } \\
\text { Sig. }\end{array}$ \\
\hline $\begin{array}{l}\text { Jumlah } \\
\text { trombosit } \\
\begin{array}{l}\text { Agregasi } \\
\text { ADP 10 }\end{array}\end{array}$ & 289.33 & 66.092 & 161 & 510 & 0.286 \\
$\begin{array}{l}\text { Agregasi } \\
\text { ADP 5 }\end{array}$ & 41.83 & 13.744 & 16 & 68 & 0.995 \\
\hline
\end{tabular}

Setelah dilakukan uji normalitas data Kolmogorov-Smirnov didapatkan untuk jumlah trombosit $P=0,286$, nilai agregasi trombosit yang menggunakan ADP $10 \mu \mathrm{m}$ $P=0,995$, dan nilai agregasi trombosit yang menggunakan ADP $5 \mu \mathrm{m} P=0,258$; hal ini menunjukkan ketiga data tersebut terdistribusi normal dengan nilai $P>0,5$ (Tabel 2).

Uji korelasi Pearson memperlihatkan bahwa hasil analisis antara jumlah trombosit dan nilai agregasi trombosit 
dengan ADP $10 \mu \mathrm{m}$ memperoleh $P=0,22$; dan dengan ADP $5 \mu \mathrm{m}$ memperoleh $P=$ 0,08 , yang berarti tidak terdapat hubungan antara jumlah trombosit dan nilai agregasi trombosit baik dengan ADP $10 \mu \mathrm{m}$ maupun ADP $5 \mu \mathrm{m}$ karena nilai kemaknaan keduanya $>0,05$. Hasil penelitian ini berbeda dengan penelitian Ferreiro et al. ${ }^{11}$ yang menyatakan bahwa DMT2 berperan penting dalam hiperaktivasi trombosit.

Tabel 3. Analisis hubungan jumlah trombosit dengan nilai agregasi trombosit ADP $10 \mu \mathrm{m}$ dan ADP $5 \mu \mathrm{m}$ menggunakan uji korelasi Pearson

\begin{tabular}{cc}
\hline & $P$ \\
& Sig. (2-tailed) \\
\hline Jumlah trombosit & 0,22 \\
Agregasi ADP 10 & 0,08 \\
\hline $\begin{array}{c}\text { Jumlah trombosit } \\
\text { Agregasi ADP 5 }\end{array}$ & 0. \\
\hline
\end{tabular}

Penyandang DMT2 sering mengalami komplikasi makro dan mikrovaskular, seperti aterosklerotik kardiovaskular dan strok. $^{5,13}$ Hal ini mungkin disebabkan karena pada DMT2, trombosit tetap diproduksi bila terjadi cedera jaringan dan bila jumlahnya mulai menurun dalam sirkulasi. Akibat percepatan pergantian trombosit (platelet turnover) maka trombosit yang dihasilkan masih imatur, berukuran lebih besar, dan bersifat lebih reaktif. Trombosit demikian lebih mudah mengalami aktivasi, adesi, dan agregasi yang berpartisipasi terhadap terjadinya komplikasi vaskular pada DMT2.

Hasil penelitian ini juga menunjukkan bahwa peningkatan jumlah trombosit tidak selalu disertai peningkatan agregasi trombosit. Hal ini mungkin disebabkan saat terjadi turn over trombosit yang berkaitan dengan jumlah produksi trombosit tidak bersamaan dengan saat terjadi hiperaktivasi trombosit untuk beragregasi walaupun kedua keadaan ini bisa terjadi pada pasien DMT2.

Keterbatasan dalam penelitian ini yaitu antara lain terbatasnya jumlah sampel dan penggunaan berbagai macam jenis obat antidiabetik oleh subjek penelitian.

\section{SIMPULAN}

Tidak terdapat hubungan bermakna antara jumlah trombosit dan nilai agregasi trombosit pada pasien diabetes melitus tipe 2 di Poliklinik Endokrin-Metabolik Bagian Penyakit Dalam RSUP Prof. Dr. R. D. Kandou Manado.

\section{SARAN}

1. Dilakukan penelitian dengan memeriksa MPV (mean platelet volume) yang menjadi indikator aktivitas trombosit.

2. Meningkatkan jumlah sampel penelitian untuk menghindari terjadinya bias dalam penelitian.

\section{DAFTAR PUSTAKA}

1. Guyton AC, Hall JE. Insulin, glucagon dan diabetes melitus. In: Guyton AC, Hall JE, editors. Buku Ajar Fisiologi Kedokteran (Edisi 11). Jakarta: EGC, 2008.

2. Kementerian Kesehatan Republik Indonesia. Tahun 2030 prevalensi diabetes melitus di Indonesia mencapai 21.3 juta orang. [cited 2012 Oct 2]. Available from: http://www.depkes.go.id/index.php/berita/ press-release/414-tahun-2030-prevalensidiabetes-melitus-di-indonesia-mencapai213-juta-orang.html.

3. Güven FMK, Yilmaz A, Aydin $\mathbf{H}$, Korkmaz I, Eren SH. Platelet aggregation responses in type 2 diabetic patients. Health. 2010;2:708-12.

4. Yngen M. Platelet function in diabetes mellitus [Thesis]. Solna: Clinical Pharmacology Unit Karolinska University Hospital; 2005. 
5. Nneka NI, Uchenna MA, Chinyere EC, Ikechukwu EA, Onyemaechi OO, Nwobi EJ. Platelet activity in patients with type 2 diabetes in eastern Nigeria. Res. J. Pharmacol. 2012;6(3):48-51.

6. Kodiatte TA, Manikyam UK, Rao SB, Jagadish TM, Reddy M, Lingaiah M, et al. Mean platelet volume in type 2 diabetes mellitus. Journal of Laboratory Physicians 2012;4:5-9.

7. Dogru T, Tasci I, Naharcı MI, Sönmez A, Erdem G, Kılıç S. Mean platelet volume levels in metabolic syndrome. The Anatolian Journal of Clinical Investigation. 2007;1(2):99-105.

8. Zuberi B F, Akhtar N, Afsar S. Comparison of mean platelet volume in patients with diabetes mellitus, impaired fasting glucose, and nondiabetic subjects. Singapore Med J Original Article. 2008;49(2):114.

9. Madan R, Gupta B, Saluja S, Kansra UC, Tripathi BK, Guliani BP. Coagulation profile in diabetes and its association with diabetic microvascular complications. JAPI 2009:58:481-84.

10. Saboor M, Moinuddin, Ilyas S. Platelets structural, functional, and metabolic alterations in diabetes mellitus. 2012. [cited 2012 Oct 2]. Available from: http://www.pps.org.pk/PJP/8-2/Saboor.pdf.

11. Ferreiro JS, Gomez JA, Angiolillo D. Platelet abnormalities in diabetes mellitus. Diabetes and Vascular Research. 2010;7:251-59.

12. Prima A. Perbedaan pola gangguan hemostasis antara penyakit ginjal kronik prehemodialisis dengan diabetes mellitus dan non diabetes mellitus [Tesis]. Semarang: Fakultas Kedoteran Universitas Diponegoro; 2008.

13. Subekti I. Neuropati diabetik. In: Sudoyo AW, Setiyohadi B, Alwi I, Simadibrata M, Setiati S, editors. Buku Ajar Ilmu Penyakit Dalam (Edisi V). Jakarta: InternaPublishing, 2009; p. 1947-51. 